\title{
PERENCANAAN STRATEGIK BERORIENTASI KEBERLANJUTAN BISNIS MENGGUNAKAN TRIPLE LAYER BUSINESS MODEL CANVAS STUDI KASUS: GHI TRAINING
}

\author{
BUSINESS SUSTAINABILITY ORIENTED STRATEGIC PLANNING \\ USING TRIPLE LAYER BUSINESS MODEL CANVAS CASE STUDY: GHI TRAINING
}

\author{
Muhammad Sigit Susanto")1, Mukhamad Najib**), dan Arry Ekananta*) \\ *) Sekolah Bisnis, IPB University \\ Jl. Pajajaran Bogor 16151, Indonesia \\ ${ }^{* *}$ Departemen Manajemen, Fakultas Ekonomi dan Manajemen, IPB University \\ Jl. Agatis Kampus IPB Darmaga, Bogor 16680, Indonesia
}

\begin{abstract}
Changes in the character of skills training customers towards the era of online learning due to the COVID19 pandemic have created a gap between business planning and reality. Therefore it is necessary to do intervene through strategic planning that considering stakeholder expectations as well as managing various factors that affect business sustainability. The aims of this study: (1) To identify strategic factors of business; (2) To formulate sustainable business development strategies. This research uses a descriptive approach through a case study at GHI Training during October and November 2020. Research data processing using IE matrix and TLBMC. Based on the evaluation results obtained 17 external strategic factors with an EFE score of 3,00 and 15 internal strategic factors with an IFE score of 2,87. The company is in a strong internal position and can respond well to opportunities and threats. Through the IE matrix, the company is placed in a hold and maintain position, so it is advisable to focus on the strategy of market penetration and product development. Essentially, from a theoretical and practical point of view, the use of TLBMC can help management to see comprehensively the company's business model and its relation to business sustainability.
\end{abstract}

Keywords: strategic planning, business sustainability, COVID19, skill training, triple layer business model canvas

\begin{abstract}
Abstrak: Perubahan karakter pelanggan pelatihan keahlian menuju era pembelajaran online akibat pandemi COVID19 menimbulkan kesenjangan antara perencanaan bisnis dengan kondisi nyata yang dihadapi. Oleh karenanya perlu dilakukan intervensi melalui perencanaan strategik yang memperhatikan harapan stakeholder sekaligus mengelola berbagai peluang dan ancaman yang berpengaruh terhadap keberlanjutan bisnis. Penelitian ini bertujuan (1) Mengidentifikasi faktor eksternal dan internal perusahaan; (2) Merumuskan alternatif strategi pengembangan bisnis yang lebih berkelanjutan di masa depan. Penelitian ini menggunakan pendekatan deskriptif melalui studi kasus pada GHI Training selama bulan Oktober dan November 2020. Pengolahan data penelitian menggunakan matriks IE dan Triple Layer Business Model Canvas. Berdasarkan hasil evaluasi diperoleh 17 faktor strategis eksternal dengan nilai EFE 3,00 dan 15 faktor strategis internal dengan nilai IFE 2,87 . Perusahaan berada dalam posisi internal yang cukup kuat serta dapat merespon dengan baik peluang dan ancaman. Pemetaan posisi perusahaan dalam matriks IE menempatkan perusahaan pada kondisi menjaga dan mempertahankan, sehingga disarankan fokus pada strategi penetrasi pasar dan pengembangan produk. Secara esensial dari sudut pandang teoritis maupun praktik penggunaan TLBMC dapat membantu manajemen melihat dengan komprehensif model bisnis yang dikembangkan dan kaitannya dengan isu lingkungan maupun sosial yang berpengaruh terhadap keberlanjutan bisnis.
\end{abstract}

Kata kunci: perencanaan strategik, keberlanjutan bisnis, COVID19, pelatihan keahlian, triple layer business model canvas

\footnotetext{
${ }^{1}$ Alamat korespondensi:

Email: sigit.ms@apps.ipb.ac.id
} 


\section{PENDAHULUAN}

Riset yang dilakukan oleh Lembaga Demografi Universitas Indonesia memperoleh fakta bahwa ketidaksesuaian jenis pekerjaan dengan bidang pendidikan mencapai 60,62\% (LD UI, 2018). Keterhubungan dan kesesuaian (link and match) antara pendidikan dan kebutuhan industri belakangan menjadi salah satu topik yang sering dibicarakan. Tingginya angka pengangguran diyakini menjadi salah satu indikator minimnya link and match antara pendidikan dan dunia kerja. Hal ini senada dengan penelitian yang menyatakan bahwa education missmatch berpengaruh positif terhadap peningkatan angka pengangguran (Amador 2008 dan Diem, 2014). Dalam konteks link and match sebagian besar masyarakat, khususnya sektor industri, menilai bahwa sistem pendidikan ditentukan oleh perkembangan kebutuhan masyarakat, sebagaimana juga dinyatakan oleh Puncreobutr (2016). Hal ini mengindikasikan bahwa dalam konsep link and match industri menjadi pemimpin, sementara pendidikan hanya menyuplai kebutuhan tersebut. Meski pendekatan tersebut tidak sepenuhnya salah, seharusnya pendidikan tidak serta merta tunduk pada pemenuhan kebutuhan keterampilan tertentu atau memfasilitasi pengembangan bakat yang diinginkan oleh industri. Hal tersebut mempertimbangkan bahwa pendidikan merupakan formulasi berbagai aspek yang tidak hanya fokus pada aspek keterampilan namun juga mengandung beragam, nilai, norma, moralitas dan pengembangan wawasan yang tidak dapat diabaikan. Oleh karenanya, kehadiran lembaga yang fokus pada pengembangan keterampilan berbasis kepakaran sebuah perguruan tinggi menjadi kebutuhan untuk menjembatani kepentingan industri dan keterbatasan perguruan tinggi tersebut.

Peluang ini berusaha dioptimalkan oleh Universitas GHI dengan mendirikan unit usaha bidang pengembangan keterampilan SDM, yakni GHI Training. Dalam perjalanan pengelolaan bisnisnya, GHI Training mengalami perkembangan kinerja usaha yang turut dipengaruhi oleh iklim bisnis dan situasi perekonomian nasional. Wabah Corona Virus Disease (COVID19) yang muncul di akhir tahun 2019 turut berdampak terhadap perekonomian Indonesia yang sempat mengalami resesi. Hal ini dipicu kebijakan pemerintah yang menetapkan kebijakan pembatasan fisik, yang kemudian diikuti kebijakan Pembatasan Sosial Berskala Besar (Pemerintah RI, 2020). Dalam konteks bisnis, kondisi krisis menghadirkan tantangan dalam pengelolaan bisnis sekaligus membuka peluang-peluang baru dalam pengembangan bisnis GHI Training. Kondisi pembatasan sosial selama pandemi berlangsung, turut merubah pola dan karakter masyarakat dalam belajar. Metode pembelajaran online dalam waktu singkat menjadi gaya baru dalam pengembangan kapasitas SDM di tengah berbagai keterbatasan. Hal ini sejalan dengan penelitian Sun et al. (2020) dan Bao (2020) yang menggambarkan pergeseran pola pembelajaran tatap muka menjadi pembelajaran online dengan dukungan teknologi.

Perubahan karakter pelanggan (khususnya pada pelatihan keahlian) menuju era pembelajaran online awalnya diprediksi manajemen GHI Training baru mulai eksis pada tahun 2021. Hal ini dikarenakan pemenuhan infrastruktur khususnya terkait kegiatan praktik (hands-on) yang membutuhkan pendekatan berbeda dibanding pelatihan pada umumnya. Namun, situasi pembatasan fisik membuat tren pembelajaran online mendadak maju ke pertengahan tahun 2020. Hal ini menciptakan celah (gap) dalam perencanaan bisnis GHI Training terkait antisipasi pengembangan model bisnis pelatihan online. Celah (gap) yang terjadi tercermin dalam penerimaan perusahaan yang turun drastis karena praktis tidak beroperasi sejak pertengahan Maret hingga awal Mei. Melalui laporan keuangan perusahaan diketahui bahwa pendapatan perusahaan tahun 2020 turun sebesar 39,44\% dibandingkan tahun sebelumnya. Research gap ini menjadi perhatian peneliti dalam menghasilkan suatu rekomendasi perencanaan strategik yang diharapkan dapat memenuhi harapan stakeholder dengan turut memperhatikan berbagai ancaman dan peluang dalam menghadapi situasi krisis yang ada.

Penelitian model bisnis merupakan salah satu jenis penelitian yang cukup populer dalam beberapa tahun ke belakang. Meski demikian penelitian model bisnis berkelanjutan dengan pendekatan Triple Layer Business Model Canvas (TLBMC) relatif baru berkembang sejak tahun 2015. Mulai dipopulerkan oleh Joyce dan Paquin (2016) beberapa riset menggunakan pendekatan ini mulai berkembang diantaranya penelitian oleh Qodri et al. (2019), Sari (2019), García-Muiña et al. (2020). Konsep TLBMC dipilih karena memiliki kelebihan diantaranya memberi gambaran global tentang model sebuah bisnis dalam visual yang relatif sederhana. Selain itu TLBMC dapat digunakan untuk mendukung inovasi model bisnis yang berorientasi keberlanjutan. Hal tersebut karena TLBMC mengedepankan 
pendekatan keberlanjutan khususnya aspek sosial dan ekologi yang dikemukakan oleh Stubbs dan Cocklin (2008) sebagai pengembangan dari BMC awal. Hal ini dapat memperluas cara pandang khususnya terkait pengelolaan ekspektasi stakeholder. TLBMC juga dipandang sejalan dengan tren global yang mengkampanyekan isu pelestarian lingkungan dan pentingnya dampak sosial sebuah bisnis.

Penelitian ini bertujuan (1) Mengidentifikasi faktor eksternal dan internal yang memengaruhi keberlanjutan bisnis; (2) Merumuskan alternatif strategi pengembangan bisnis GHI Training dalam menjalankan bisnis yang lebih berkelanjutan di masa depan. Ruang lingkup penelitian difokuskan pada kajian perencanaan strategik GHI Training untuk mengantisipasi perubahan karakter pelanggan dan persaingan bisnis khususnya dalam menghadapi situasi normal baru akibat pandemi COVID19. Hasil penelitian ini berupa perumusan strategi bisnis perusahaan dengan menggunakan pendekatan model bisnis berkelanjutan.

\section{METODE PENELITIAN}

Penelitian ini dilakukan pada GHI Training selama dua bulan, sejak Oktober hingga November 2020. Penelitian ini menggunakan pendekatan deskriptif melalui studi kasus, sebagaimana penelitian sebelumnya yang banyak menggunakan pendekatan studi kasus (Wongwa, 2016; Agustini, 2017; Wulandari, 2017; Jourdan et al. 2018; Prasetyo et al. 2018). Pendekatan studi kasus umumnya menitikberatkan pada aspek pemahaman mendalam, rinci, menyeluruh atas objek tertentu (yang biasanya relatif kecil) selama kurun waktu tertentu, termasuk lingkungannya (Umar, 2010). Pemilihan objek studi kasus didasari alasan karena belum ada penelitian strategik khususnya dalam menghadapi situasi krisis pada perusahaan jasa pelatihan keahlian berbasis kepakaran perguruan tinggi. Sehingga penelitian ini diharapkan memperkaya literatur penelitian manajemen strategik pada perusahaan swasta yang bersinggungan dengan ekosistem kampus serta kental dengan budaya akademik, inovasi dan birokrasi.

Jenis data yang digunakan pada penelitian ini terdiri dari data primer dan sekunder. Data primer diperoleh dari responden yang merupakan stakeholder internal serta eksternal perusahaan dan ditentukan menggunakan pendekatan purposive sampling. Hal ini dimaksudkan agar dapat diperoleh narasumber yang kompeten, guna menjaga tingkat validitas data. Sementara itu data sekunder didapatkan melalui studi literatur dan dokumen perusahaan. Dalam rangka mengidentifikasi faktor eksternal dan internal yang memengaruhi bisnis GHI Training peneliti melakukan wawancara yang dilanjutkan dengan evaluasi faktor eksternal dan internal. Hasil evaluasi tersebut kemudian dipetakan ke dalam matriks IE untuk merumuskan alternatif strategi pengembangan bisnis GHI Training dalam menjalankan bisnis yang lebih berkelanjutan di masa depan. Selanjutnya rekomendasi strategi tersebut dipetakan ke dalam blok-blok yang terdapat dalam TLBMC untuk melihat hubungan antar elemen yang mempengaruhi keberlanjutan bisnis di masa mendatang.

Kerangka pemikiran penelitian sebagaimana terlihat pada Gambar 1 didasari oleh beragamnya potensi kepakaran Universitas GHI yang relevan dengan berbagai kebutuhan pengembangan keterampilan SDM pada berbagai jenis industri maupun profesi. Potensi bisnis ini ditangkap oleh GHI Training, namun demikian terdapat tantangan dalam pengelolaan bisnis akibat perubahan karakter pelanggan setelah hadirnya pandemi COVID19. Oleh karenanya perlu dilakukan reformulasi strategi untuk mengantisipasi tantangan tersebut.

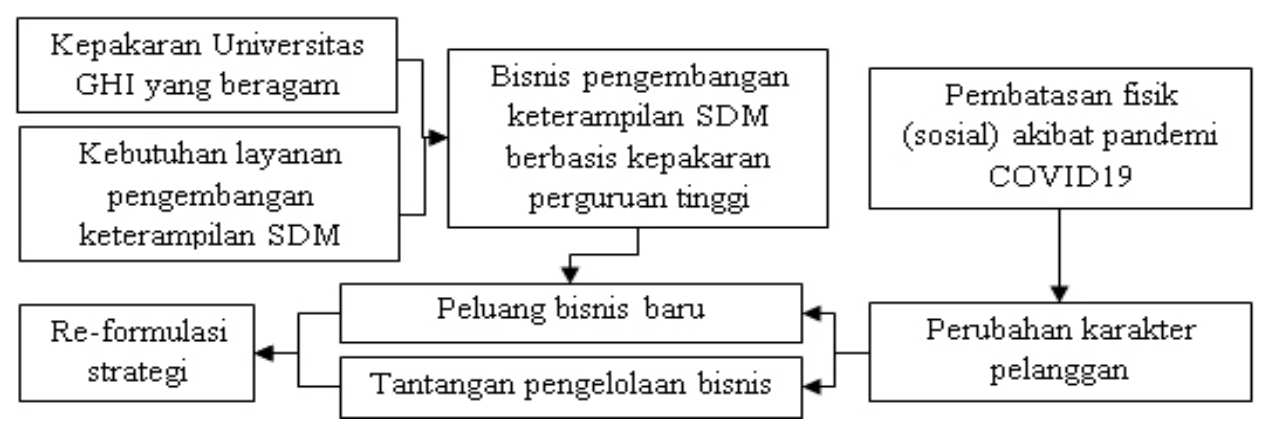

Gambar 1. Kerangka pemikiran penelitian 
Hipotesis penelitian ini adalah bahwa GHI Training memiliki model bisnis yang berkelanjutan. Hal ini didasari pemahaman bahwa dari sudut pandang ekonomi peluang bisnis pelatihan keahlian masih sangat terbuka lebar. Di sisi lain, dari sudut pandang ekologi, proses bisnis yang dijalankan perusahaan tidak banyak menggunakan material bio-fisik yang berdampak negatif bagi lingkungan. Terakhir, dari aspek sosial, perusahaan saat ini juga dipandang telah dapat menjalin kemitraan yang baik bersama stakeholder.

\section{HASIL}

\section{Analisis Faktor Strategis Eksternal dan Internal}

Analisis lingkungan eksternal dilakukan dengan tujuan untuk mengidentifikasi berbagai faktor strategis eksternal yang memengaruhi perusahaan. Analisis faktor strategis eksternal dalam penelitian ini menggunakan pendekatan analisis STEEP (Social, Technology, Economy, Ecology, Politic) dan analisis persaingan industri Portre's five forces. Hasil analisis selanjutnya dikuantifikasi menggunakan matriks EFE. Matriks EFE digunakan untuk mengukur seberapa baik respon perusahaan terhadap peluang dan ancaman yang dihadapi perusahaan.
Setiap faktor strategis diberikan bobot sesuai tingkat signifikansi pengaruhnya terhadap keberlangsungan bisnis. Jumlah total seluruh bobot yang diberikan terhadap seluruh faktor eksternal harus sama dengan satu (1,00). Sementara rating yang diberikan menggambarkan respon perusahaan terhadap peluang dan ancaman yang ada $(1,00=$ respon sangat buruk, $2,00=$ respon rata-rata, $3,00=$ respon di atas ratarata, $4,00=$ respon sangat baik). Skor merupakan hasil perkalian antara bobot faktor strategis dengan rating yang diberikan. Skor total tertinggi yang dapat dicapai oleh perusahaan adalah empat $(4,00)$ dengan skor terendah adalah satu $(1,00)$ dan rata-rata skor adalah 2,50. Skor tinggi mengindikasikan bahwa sebuah perusahaan mampu merespon dengan baik berbagai peluang maupun ancaman. Sebaliknya skor rendah menandakan bahwa strategi perusahaan belum mampu memanfaatkan peluang yang ada serta belum mampu meminimalkan pengaruh negatif dari ancaman yang muncul (David, 2011). Melalui FGD melibatkan direktur, sekretaris dan manajer diperoleh 17 faktor strategis yang dipetakan menggunakan matriks EFE dan disajikan pada Tabel 1.

Tabel 1. Matriks EFE

\begin{tabular}{lccc}
\hline & Bobot & Rating & Skor \\
\hline Peluang & & & \\
Demografi segmen pelanggan bervariasi (usia, pendidikan, pekerjaan) & 0,04 & 3,00 & 0,12 \\
Prioritas pelanggan mengikuti pelatihan: Kesesuaian topik dan kompetensi narasumber & 0,08 & 4,00 & 0,32 \\
Pelanggan memprioritaskan pelatihan tatap muka & 0,08 & 3,67 & 0,28 \\
Keterbatasan penguasaan keterampilan praktis dan penggunaan teknologi & 0,06 & 3,33 & 0,22 \\
Peningkatan kebutuhan pada semester dua & 0,04 & 2,33 & 0,10 \\
Tingkat profitabilitas pelanggan baik dan menyediakan dana pengembangan SDM & 0,03 & 2,67 & 0,09 \\
Sebagian besar (60-65\%) pelanggan tidak sensitif terhadap harga & 0,06 & 3,33 & 0,19 \\
Pelanggan mengutamakan layanan personal, kustom dan responsif & 0,04 & 3,33 & 0,15 \\
Perubahan preferensi ke arah pelatihan online pada topik-topik dasar & 0,07 & 3,00 & 0,20 \\
Barier persaingan pelatihan keahlian adalah kepakaran yang dikuasai oleh sedikit expert & 0,08 & 3,67 & 0,29 \\
Ancaman & & & \\
Keterbatasan model pelatihan yang bersifat one shoot (sekali bertemu dan tidak & 0,04 & 1,67 & 0,07 \\
berkelanjutan) & & & \\
Beberapa segmen pelanggan masih membutuhkan edukasi & 0,05 & 2,33 & 0,12 \\
Banyak pilihan program pelatihan mirip dengan yang diselenggarakan & 0,07 & 2,83 & 0,21 \\
Regulator yang menyelenggarakan pelatihan dan menjual lisensi mengurangi pangsa pasar & 0,05 & 2,67 & 0,14 \\
Kebanyakan pesaing menawarkan pelatihan dengan harga lebih rendah & 0,04 & 2,00 & 0,08 \\
Potensi persaingan ke depan akan semakin tinggi & 0,07 & 2,67 & 0,18 \\
Ketergantungan model bisnis yang tinggi terhadap trainer dan mitra & 0,08 & 3,00 & 0,25 \\
\hline Total & 1,00 & & 3,00 \\
\hline \hline
\end{tabular}


Hasil evaluasi terhadap faktor eksternal menunjukkan bahwa perusahaan sudah dapat merespon dengan baik peluang yang ada serta mengantisipasi ancaman yang muncul. Skor tinggi diberikan pada faktor yang terkait dengan substansi materi (2), metode pembelajaran tatap muka berbasis praktik (hands-on) (3) serta keberadaan expert yang kompeten (10) menggambarkan bahwa perusahaan telah menaruh perhatian yang tepat terhadap faktor esensial yang berpengaruh dalam perkembangan bisnis. Meskipun demikian, masih terdapat beberapa area yang perlu memperoleh perhatian manajemen. Salah satu aspek yang penting diperhatikan adalah ketergantungan model bisnis terhadap trainer (17). Selain itu perusahaan juga perlu mengantisipasi persaingan pada tiap kategori produk baik kondisi saat ini (13) maupun guna mengantisipasi berbagai potensi masuknya pesaing baru (16). Selain itu perlu diperkuat respon perusahaan terhadap potensi subtitusi pelatihan dengan model pembelajaran online (9).

Analisis lingkungan internal dimanfaatkan untuk mengidentifikasi faktor-faktor strategis internal yang dihadapi oleh perusahaan. Pada penelitian ini analisis faktor strategis internal dilakukan dengan menggunakan tujuh aspek fungsional perusahaan, yaitu (1) manajemen, (2) pemasaran, (3) operasi, (4) sumberdaya manusia, (5) sistem dan teknologi informasi, (6) penelitian dan pengembangan, dan (7) keuangan.
Matriks IFE digunakan untuk merangkum dan mengevaluasi kekuatan serta kelemahan utama dalam aspek fungsional perusahaan. Setiap faktor strategis diberikan bobot yang menggambarkan signifikansinya bagi keberhasilan industri perusahaan. Jumlah total seluruh bobot yang diberikan terhadap seluruh faktor internal harus sama dengan satu $(1,00)$. Sementara rating yang diberikan menggambarkan kondisi perusahaan terhadap faktor yang dinilai $(1,00=$ sangat lemah, 2,00 = lemah, 3,00 = kuat, 4,00 = sangat kuat). Faktor yang diidentifikasi sebagai kelemahan harus memperoleh nilai 1,00 atau 2,00 sementara kekuatan mesti memperoleh rating antara 3,00 atau 4,00. Hasil perkalian antara bobot dan rating akan menghasilkan skoryangjika dijumlahkan akan menghasilkan skor total organisasi. Skor total tertinggi yang dapat dicapai oleh perusahaan adalah empat $(4,00)$ dengan skor terendah adalah satu $(1,00)$ dan rata-rata skor 2,50. Skor di atas 2,50 menggambarkan kondisi internal perusahaan yang kuat (David 2011). Melalui wawancara dengan stakeholder internal dan eksterna dihasilkan 15 faktor strategis yang dipetakan menggunakan matriks IFE sebagaimana ditampilkan pada Tabel 2.

Tabel 1. Matriks IFE

\begin{tabular}{|c|c|c|c|}
\hline & Bobot & Rating & Skor \\
\hline \multicolumn{4}{|l|}{ Kekuatan } \\
\hline Citra perusahaan sudah cukup profesional dan dipercaya pelanggan & 0,09 & 4,00 & 0,35 \\
\hline Manajemen berkomitmen kuat dalam pertumbuhan perusahaan & 0,07 & 3,00 & 0,22 \\
\hline Produk sudah dikenal dan cukup mudah ditemukan pelanggan & 0,05 & 3,00 & 0,15 \\
\hline Hubungan kemitraan terjalin baik & 0,09 & 4,00 & 0,35 \\
\hline Program sangat berkualitas dan sesuai kebutuhan pasar & 0,09 & 3,67 & 0,33 \\
\hline Perusahaan memiliki sistem manajemen kinerja yang dijalankan & 0,03 & 3,67 & 0,13 \\
\hline Secara umum karyawan merasa puas terhadap perusahaan & 0,03 & 3,67 & 0,13 \\
\hline Perusahaan memberdayakan sistem dan teknologi informasi & 0,06 & 3,00 & 0,17 \\
\hline Perusahaan melakukan analisis terhadap umpan balik pelanggan & 0,09 & 3,00 & 0,27 \\
\hline Tingkat kesehatan finansial perusahaan dalam kondisi baik & 0,06 & 4,00 & 0,22 \\
\hline \multicolumn{4}{|l|}{ Kelemahan } \\
\hline Belum ada penilaian pangsa pasar dan channel pemasaran paling efektif & 0,07 & 2,00 & 0,14 \\
\hline Maintenance pelanggan dan layanan after sales belum terprogram dengan sistematis & 0,08 & 1,00 & 0,08 \\
\hline Kualitas wawasan, kepemimpinan dan keterampilan SDM bervariasi & 0,07 & 2,00 & 0,14 \\
\hline Belum memiliki manual jenjang karir & 0,06 & 1,00 & 0,06 \\
\hline Jumlah peserta pada sebagian program baru yang dikembangkan belum maksimal & 0,07 & 2,00 & 0,14 \\
\hline Total & 1,00 & & 2,87 \\
\hline
\end{tabular}


Hasil evaluasi terhadap faktor strategis internal menunjukkan bahwa kondisi internal perusahaan sudah cukup kuat. Hal tersebut tergambar oleh rating yang baik pada faktor strategis dengan bobot tinggi khususnya terkait reputasi perusahaan (1), pengelolaan hubungan kemitraan (4) dan kualitas program yang diselenggarakan (5). Namun demikian perlu ditingkatkan efektivitas analisis umpan balik pelanggan serta dipikirkan upaya proaktif untuk merawat hubungan pelanggan pasca program pelatihan diberikan (12).

\section{Perumusan Alternatif Strategi}

Perumusan alternatif strategi didahului dengan memetakan posisi strategis perusahaan menggunakan Matriks Internal-Eksternal (IE) dan dilanjutkan dengan TLBMC. Matriks IE merupakan matriks yang meringkas hasil evaluasi berbagai faktor strategis eksternal dan internal dan menempatkan perusahaan ke dalam matriks yang terdiri dari sembilan sel. Berdasarkan analisis terhadap faktor strategis eksternal (EFE) dan internal (IFE) diketahui bahwa skor total EFE perusahaan adalah 3,00 sementara nilai IFE perusahaan adalah 2,87. Pemetaan hasil evaluasi tersebut pada matrik IE menghasilkan posisi perusahaan yang berada pada sel $\mathrm{V}$ yakni dalam kondisi menjaga dan mempertahankan (Gambar 2). Implikasi strategi yang dapat digunakan pada posisi tersebut adalah melakukan penetrasi pasar
(A') sembari melakukan pengembangan produk (B'). Strategi penetrasi pasar bertujuan untuk meningkatkan pangsa pasar sebuah produk melalui usaha pemasaran yang lebih masif. Sementara strategi pengembangan produk bertujuan untuk meningkatkan penjualan dengan cara meningkatkan atau memodifikasi produk dan layanan yang ada saat ini.

\section{Triple Layer Business Model Canvas (TLBMC)}

Model bisnis dengan orientasi keberlanjutan seperti TLBMC dapat digunakan untuk memetakan model bisnisyang dijalankan perusahaandalamperspektifyang lebih luas. Berdasarkan hasil pemetaan alternatif strategi menggunakan TLBMC dapat dilihat kesinambungan strategi perusahaan pada tiga aspek yang diharapkan berperan dalam menjaga keberlanjutan bisnis, yakni ekonomi, ekologi dan sosial. Hal ini sejalan dengan hasil penelitian Furqon et al. (2019) yang menyatakan bahwa TLBMC yang digunakan dapat mendukung pengembangan usaha berkelanjutan khususnya dalam studi kasus kelompok tani kopi. Sementara Mu'min et al. (2018) menggunakan TLBMC untuk menganalisis faktor-faktor yang memengaruhi perkembangan industri tembakau di Jawa Timur. Hasilnya TLBMC dapat dijadikan sebagai dasar untuk membuat sebuah kebijakan yang mendukung pengembangan industri tembakau yang lebih holistik dan berkelanjutan.

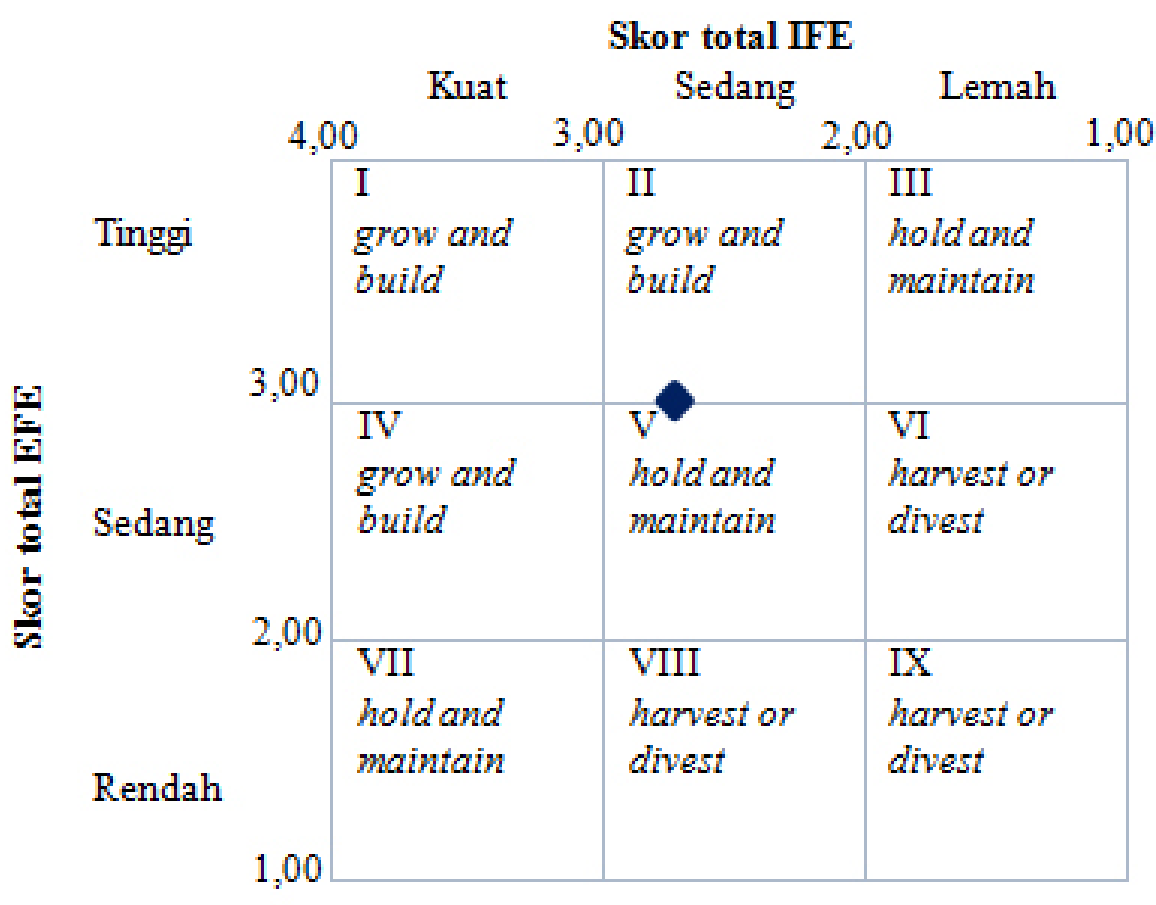

Gambar 2. Matriks IE GHI Training 
Sebagaimana penelitian yang dilakukan oleh Joyce dan Paquin (2016), melalui TLBMC juga dapat dilihat hubungan vertikal antar lapisan, baik ekonomi, ekologi maupun sosial. Pendekatan tersebut juga dilakukan pada penelitian ini untuk memperluas sudut pandang model bisnis yang dijalankan (Gambar 3, Gambar 4, Gambar 5). Poin yang dicetak tebal pada blok TLBMC merupakan pengembangan dari strategi utama yang dikembangkan sebelumnya dan diberi penanda (A' dan B') untuk membantu melihat keterhubungan antara strategi utama dan alternatifnya.

Perusahaan memposisikan diri sebagai penyedia solusi bagi pengembangan keterampilan teknis berkualitas terkait sains terapan. Solusi tersebut berbentuk modul yang relevan, trainer yang kompeten serta dukungan layanan yang memudahkan pelanggan untuk menjawab berbagai masalah yang ada di lapangan. Program yang diselenggarakan oleh perusahaan diidentifikasi sebagai nilai fungsional yang berwujud 100 pelatihan dalam satu tahun. Program-program pelatihan tersebut diharapkan dapat meningkatkan kualitas hidup manusia dan memberikan nilai tambah pada proses bisnis pelanggan. Nilai tambah tersebut dapat diperoleh melalui pengembangan keterampilan SDM yang akan meningkatkan mutu, efektivitas dan efisiensi proses kerja. Perusahaan juga diharapkan dapat memaksimalkan peran sebagai penghubung perguruan

Segmen pelanggan yang hendak dilayani perusahaan terdiri dari SDM dengan usia 25-40 tahun yang beraktivitas di daerah perkotaan. Lebih spesifik target pelanggan merupakan personel yang bekerja pada korporasi, bisnis skala menengah, lembaga pemerintahan, serta perorangan yang menjalankan profesi tertentu seperti akademisi, dokter hewan, paramedik veteriner, serta pengendali hama kesehatan. Melalui kanvas lingkungan dapat dilihat bahwa tidak terdapat dampak negatif bagi lingkungan selama fase penggunaan produk yang ditawarkan perusahaan kepada pelanggan. Para pengguna akhir diharapkan akan menerima manfaat dalam jangka panjang yang bersifat intangible dan berpengaruh dalam meningkatkan kualitas produk serta layanan yang dihasilkan pelanggan sekaligus meningkatkan efektivitas dan efisiensi proses bisnis yang dijalankan.

\begin{tabular}{|c|c|c|c|c|c|}
\hline \multirow[t]{2}{*}{$\begin{array}{l}\text { Kemitraan } \\
\text { - Universitas GHI (unit) } \\
\text { - Pemasok venue dan } \\
\text { katering } \\
\text { - Pemasok kit } \\
\text { - Pelajar dan mahasiswa } \\
\text { magang (MC dan } \\
\text { digital marketer) } \\
\text { - Content creator untuk } \\
\text { blog }\end{array}$} & $\begin{array}{l}\text { Aktivitas utama } \\
\text { - Riset dan } \\
\text { pengembangan produk } \\
\text { serta layanan online } \\
\text { training (B') } \\
\text { - Apresiasi dan } \\
\text { regenerasi trainer (B') } \\
\text { - Pemasaran dan } \\
\text { penjualan } \\
\text { - Pelaksanaan } \\
\text { operasional program } \\
\text { - Pemeliharaan dan } \\
\text { pengembangan sistem } \\
\text { informasi (A') }\end{array}$ & \multicolumn{2}{|c|}{$\begin{array}{l}\text { Penyedia solusi } \\
\text { pengembangan } \\
\text { keterampilan/ } \\
\text { keahlian teknis } \\
\text { berkualitas terkait } \\
\text { sains terapan } \\
\text { - Modul dan trainer } \\
\text { yang berkualitas } \\
\text { dan sesuai preferensi } \\
\text { pelanggan }\end{array}$} & $\begin{array}{l}\text { Hubungan pelanggan } \\
\text { - Pelibatan pelanggan } \\
\text { dalam pengembangan } \\
\text { produk (co-creation) } \\
\text { - Blog dan medsos yang } \\
\text { informatif (A') } \\
\text { - Pelatihan terstruktur, } \\
\text { - sertifikasi (B') } \\
\text { - Penawaran khusus } \\
\text { - Webinar gratis untuk } \\
\text { memperluas pasar } \\
\text { - Penguatan brand lewat } \\
\text { souvenir (A') } \\
\text { - Layanan pelanggan } \\
\text { melalui whatsapp }\end{array}$ & $\begin{array}{l}\text { Segmen pelanggan } \\
\text { - Segmen korporat } \\
\text { - Segmen instansi } \\
\text { pemerintahan } \\
\text { - Segmen akademisi } \\
\text { - Segmen perorangan } \\
\text { Usia } 25-40 \text { tahun } \\
\text { beraktivitas di daerah } \\
\text { urban }\end{array}$ \\
\hline & $\begin{array}{l}\text { Sumberdaya kunci } \\
\text { - SDM berpengetahuan, } \\
\text { terlatih dan berorientasi } \\
\text { kepuasan pelanggan } \\
\text { - Teknologi informasi } \\
\text { - Kantor }\end{array}$ & & & \begin{tabular}{l}
\multicolumn{1}{c}{ Saluran } \\
- Pemasaran berbasis \\
konten (A') \\
- Pelatihan tatap muka \\
dan daring dilengkapi \\
dengan hands-on (B') \\
- Pengumpulan umpan \\
balik pelanggan \\
- Layanan purnajual (A')
\end{tabular} & \\
\hline \multicolumn{3}{|c|}{$\begin{array}{l}\text { Struktur biaya } \\
\text { - HPP: Narasumber dan fasilitator, venue, katering, kit dan } \\
\text { pemasaran } \\
\text { Biaya usaha: biaya pegawai, sewa kantor, sistem informasi, } \\
\text { penyusutan peralatan bahan praktikum, penyusutan peralatan } \\
\text { pendukung pelatihan (A') }\end{array}$} & \multicolumn{3}{|c|}{$\begin{array}{l}\text { Arus pendapatan } \\
\text { - Hasil penjualan pelatihan reguler dan pelatihan in-house (offline } \\
\text { dan online) } \\
\text { - Hasil penjualan video on demand (B') } \\
\text { - Sponsorship (dana, peminjaman alat praktikum) }\end{array}$} \\
\hline
\end{tabular}




\begin{tabular}{|c|c|c|c|c|}
\hline \multirow[t]{2}{*}{$\begin{array}{l}\text { Pengalihdayaan } \\
\text { - Energi listrik, gas dan } \\
\text { air untuk venue serta } \\
\text { katering } \\
\text { - Bahan pangan untuk } \\
\text { katering } \\
\text { - Bahan kimia untuk kit }\end{array}$} & $\begin{array}{l}\quad \text { Produksi } \\
\text { Diskusi bersama } \\
\text { pelanggan dan mitra } \\
\text { berdasarkan umpan balik } \\
\text { pelanggan sehingga } \\
\text { tidak berdampak bagi } \\
\text { lingkungan }\end{array}$ & \multirow[t]{2}{*}{\begin{tabular}{l}
\multicolumn{1}{|c}{ Nilai fungsional } \\
Minimal 100 Pelatihan \\
dalam satu tahun
\end{tabular}} & $\begin{array}{l}\text { Akhir masa penggunaan } \\
\text { Akhir masa penggunaan } \\
\text { tidak menghasilkan } \\
\text { limbah dan emisi }\end{array}$ & \multirow[t]{2}{*}{$\begin{array}{l}\text { Fase penggunaan } \\
\text { Fase penggunaan tidak } \\
\text { menghasilkan limbah } \\
\text { dan emisi }\end{array}$} \\
\hline & $\begin{array}{l}\text { Bahan } \\
\text { - Laptop (personal } \\
\text { computer) } \\
\text { - Gedung perkantoran } \\
\text { - Bahan praktikum }\end{array}$ & & $\begin{array}{l}\text { Distribusi } \\
\text { - Training online lebih } \\
\text { menghemat penggunaan } \\
\text { sumberdaya alam (B') } \\
\text { - Pemanfaatan sistem } \\
\text { dan teknologi informasi } \\
\text { menghemat penggunaan } \\
\text { kertas, tinta dan limbah } \\
\text { perkantoran lainnya (A') }\end{array}$ & \\
\hline \multicolumn{2}{|c|}{ Dampak negatif } & \multicolumn{3}{|c|}{$\begin{array}{l}\text { Manfaat positif } \\
\text { - Terdapat manfaat jangka panjang terhadap lingkungan melalui } \\
\text { berbagai pelatihan (terkait penggunaan bahan kimia dan } \\
\text { konservasi lingkungan) } \\
\text { - Proses bisnis tidak signifikan menghasilkan emisi dan limbah atau } \\
\text { menurunkan kualitas air, tanah maupun udara } \\
\text { - Proses bisnis mampu meminimalisir penggunaan kertas, tinta dan } \\
\text { limbah perkantoran pada umumnya (A') }\end{array}$} \\
\hline
\end{tabular}

Gambar 4. Kanvas ekologi TLBMC

\begin{tabular}{|c|c|c|c|c|c|}
\hline \multirow[t]{2}{*}{$\begin{array}{l}\text { Komunitas lokal } \\
\text { - } \text { Membangun pola } \\
\text { kemitraan bersama } \\
\text { unit Universitas GHI } \\
\text { - } \text { Pelibatan } 100 \text { orang } \\
\text { trainer pertahun } \\
\text { - Perlindungan IP } \\
\text { - } \text { Menjalin kolaborasi } \\
\text { dengan perusahaan } \\
\text { dalam grup bisnis }\end{array}$} & \begin{tabular}{|l|}
\multicolumn{1}{c|}{ Tata kelola } \\
- Perusahaan berbentuk \\
PT dengan saham \\
dimiliki Universitas \\
GHI \\
- Struktur organisasi \\
mengadopsi pola \\
divisi yang sederhana \\
dan ramping berbasis \\
kategori produk \\
- Pengambilan keputusan \\
yang transparan
\end{tabular} & \multirow{2}{*}{\multicolumn{2}{|c|}{$\begin{array}{l}\quad \text { Nilai sosial } \\
\text { - Meningkatkan } \\
\text { kualitas hidup } \\
\text { manusia dan } \\
\text { memberikan nilai } \\
\text { tambah pada proses } \\
\text { bisnis pelanggan } \\
\text { - Menjadi penghubung } \\
\text { perguruan tinggi dan } \\
\text { masyarakat }\end{array}$}} & \begin{tabular}{|l|}
\multicolumn{1}{|c|}{ Sosial budaya } \\
Budaya masyarakat \\
yang sejalan dengan \\
aktivitas bisnis perusahaan \\
adalah pembelajaran dan \\
perbaikan berkelanjutan
\end{tabular} & \multirow[t]{2}{*}{\begin{tabular}{l}
\multicolumn{1}{c}{ Pengguna akhir } \\
Meningkatkan \\
keterampilan teknis \\
SDM yang berdampak \\
pada peningkatan, mutu \\
produk serta efektivitas \\
dan efisiensi proses \\
kerja
\end{tabular}} \\
\hline & $\begin{array}{l}\quad \text { Karyawan } \\
\text { - Karyawan perusahaan } \\
\text { berjumlah lima orang } \\
\text { yang berasal dari } \\
\text { daerah dan multi- } \\
\text { gender } \\
\text { - Sistem pengembangan } \\
\text { SDM melalui } \\
\text { pendampingan, } \\
\text { pelatihan, } \\
\text { pendelegasian tugas }\end{array}$ & & & $\begin{array}{l}\text { Skala jangkauan } \\
\text { - Pelanggan berasal } \\
\text { dari seluruh daerah di } \\
\text { Indonesia, regional Asia } \\
\text { Tenggara dan negara } \\
\text { Uni Eropa } \\
\text { - Kemitraan bersama } \\
\text { Universitas GHI, } \\
\text { asosiasi, LSP, HA-GHI } \\
\text { dalam lingkup nasional } \\
\text { (A') }\end{array}$ & \\
\hline \multicolumn{3}{|c|}{$\begin{array}{l}\text { Dampak negatif sosial } \\
\text { mbuhkan budaya dan mindset instan dalam } \\
\text { arena pelatihan bersifat short course yang } \\
\text { murah dibanding perkuliahan vokasional } \\
\text { utuhan tenaga kerja bidang pelatihan akibat } \\
\text { roses bisnis (A') }\end{array}$} & \multicolumn{3}{|c|}{$\begin{array}{l}\text { Manfaat positif sosial } \\
\text { tivitas dan efisiensi proses bisnis } \\
\text { litas hasil kerja sesuai persyaratan } \\
\text { diaan tenaga kerja terampil dan kompeten } \\
\text { akaran dan inovasi perguruan tinggi dengan } \\
\text { dustri }\end{array}$} \\
\hline
\end{tabular}


Proposisi nilai perusahaan berusaha disampaikan kepada setiap segmen pelanggan dimulai dengan menggunakan saluran pemasaran berbasis konten baik dengan metode konvensional maupun digital. Saluran utama penyampaian proposisi nilai tersebut adalah melalui program pelatihan tatap muka maupun daring yang dilengkapi dengan kegiatan praktik (hands-on). Perusahaan juga menyediakan saluran interaktif yang berbentuk pengumpulan umpan balik pelanggan guna meningkatkan kualitas produk dan layanan di masa mendatang. Meski demikian saluran masih perlu dilengkapi dengan model layanan purnajual yang dapat menjaga keberlanjutan hubungan perusahaan dengan pelanggan dalam jangka panjang. Skala jangkauan perusahaan terus berkembang dengan pelanggan yang berasal dari dalam maupun luar negeri. Jangkauan ini diharapkan terus membesar sejalan dengan implementasi model pembelajaran jarak jauh yang dikembangkan serta implementasi model kemitraan bersama berbagai asosiasi, LSP serta himpunan alumni dalam lingkup nasional. Dalam kanvas lingkungan, aktivitas distribusi nilai secara umum memberikan benefit bagi lingkungan. Hal ini dikarenakan hadirnya diversifikasi model layanan berupa pelatihan online yang dapat menghemat penggunaan sumber daya berupa energi listrik, gas dan bahan pangan untuk keperluan venue dan katering. Model pelatihan online juga mampu mengurangi penggunaan bahan kimia yang umumnya digunakan dalam penyediaan kit pelatihan. Sementara dari sudut pandang proses bisnis, pemanfaatan sistem dan teknologi informasi dinilai mampu mengurangi penggunaan kertas dan tinta yang banyak digunakan pada model kerja konvensional.

Perusahaan telah mengembangkan model bisnis yang sejalan dengan aspek sosial dan budaya yang berkembang di masyarakat terkait pembelajaran dan perbaikan berkelanjutan. Karakter pelanggan yang menginginkan metode (cara) terbaik dalam melakukan sebuah pekerjaan serta menyelesaikan berbagai kasus yang ditemui di lapangan sejalan dengan berbagai program yang ditawarkan oleh perusahaan. Hal ini juga mendasari model pengembangan produk dengan pendekatan co-creation yang dijalankan perusahaan. Pengembangan produk bersama pelanggan diharapkan dapat langsung mengakses masalah (pain point) yang dihadapi pelanggan, sehingga lebih mudah bagi perusahaan untuk menyediakan solusi yang sesuai. Perusahaan juga dapat membangun hubungan yang berkelanjutan dengan para pelanggannya dengan menyediakan beragam informasi yang berguna baik melalui blog maupun pembaruan informasi pada media sosial yang dimiliki. Levelisasi berbagai modul pelatihan juga diharapkan dapat menjaga hubungan perusahaan dengan pelanggan dalam jangka panjang. Hal ini karena perusahaan mampu menyiapkan learning journey sesuai dengan kebutuhan pelanggan. Selain hal tersebut, guna memperluas pasar maka dibangun pola hubungan dengan memberikan beragam penawaran spesial yang disesuaikan dengan kondisi pelanggan yang dituju (misal: webinar gratis untuk memperbaharui informasi seputar keterampilan yang dibutuhkan, outlook bisnis tahunan, potongan biaya pelatihan, program in-house, product bundling). Manajemen juga dapat melakukan upaya penguatan brand dengan menyiapkan beragam souvenir yang dapat diberikan kepada pelanggan. Terakhir, penyediaan layanan pelanggan yang responsif juga penting diperhatikan oleh perusahaan untuk memastikan kepuasan pelanggan tetap terjaga khususnya dalam aspek penyampaian informasi yang dibutuhkan. Sementara itu dalam sudut pandang ekologi, produk dan layanan yang dikembangkan perusahaan juga tidak menghasilkan limbah yang berdampak negatif bagi lingkungan.

Proses penyampaian proposisi nilai kepada tiap segmen pelanggan menghasilkan arus pendapatan bagi perusahaan. Selain arus pendapatan yang berasal dari pelatihan tatap muka baik reguler maupun in-house, ke depan perusahaan dapat memperoleh penerimaan dari model pelatihan online. Selain itu model video on demand juga diperkirakan dapat menjadi sumber penerimaan baru yang potensial. Sementara itu model lain penerimaan yang dapat dimanfaatkan perusahaan adalah berbagai bentuk sponsorship melalui penyediaan slot presentasi, penyewaan booth produk hingga peminjaman peralatan pendukung praktikum. Program yang disediakan perusahaan secara tidak langsung juga berimplikasi positif bagi lingkungan. Hal ini terjadi khususnya pada program pelatihan yang berorientasi pada upaya pelestarian ekosistem hutan, konservasi keanekaragaman hayati serta iklim. Perusahaan juga berupaya mengurangi dampak negatif terhadap lingkungan khususnya penggunaan kertas dan tinta dengan menjalankan proses bisnis berbasis platform online. Secara sosial, solusi yang ditawarkan perusahaan diharapkan dapat meningkatkan efektivitas dan efisiensi proses bisnis yang dijalankan pelanggan serta meningkatkan kualitas hasil kerja (output) sesuai standar yang dipersyaratkan. Program pelatihan yang diselenggarakan juga mendukung penyediaan tenaga kerja terampil dan kompeten untuk menghasilkan 
produk dan layanan yang berkualitas. GHI Training juga diharapkan berperan sebagai penghubung antara kepakaran dan inovasi perguruan tinggi dengan masyarakat serta industri.

Dalam rangka menghasilkan proposisi nilai maka dilakukan berbagai aktivitas kunci. Aktivitas kunci pertama yang dilakukan perusahaan adalah riset dan pengembangan produk dan layanan. Perusahaan disarankan mengembangkan produk-produk dengan memperluas kategori (menambah bidang ilmu untuk memperbesar portofolio produk yang ada). Selain itu perusahaan juga disarankan untuk mengembangkan produk existing dengan cara membagi modul menjadi modul lain yang lebih spesifik dan terstruktur sesuai dengan level kompetensi yang relevan. Proses produksi ini tidak berdampak negatif bagi lingkungan karena dilakukan melalui proses diskusi bersama pelanggan dan mitra berdasarkan penilaian terhadap kebutuhan pelanggan yang disampaikan melalui form kuesioner pada portal online. Sementara untuk jenis layanan, perusahaan dapat mengembangkan program pelatihan online maupun blended learning yang dapat diselenggarakan secara langsung (realtime) maupun menggunakan pendekatan video on demand. Hal ini sejalan dengan penelitian yang dilakukan oleh Basilaia dan Kvavadze (2020) yang menekankan pentingnya transisi berbagai model pembelajaran menggunakan online platform untuk digunakan di masa mendatang. Mengingat trainer merupakan aktor kunci dalam bisnis pelatihan maka perusahaan perlu melakukan berbagai upaya untuk melakukan regenerasi trainer sembari menjaga tingkat loyalitas trainer. Dalam rangka memastikan penyampaian proposisi nilai dengan baik maka perusahaan perlu melakukan aktivitas pemasaran, penjualan dan operasi (pelaksanaan program pelatihan) yang efektif efisien dan proper. Perusahaan juga perlu melakukan pemeliharaan dan pengembangan sistem baik sistem informasi (software dan hardware) maupun sistem mutu. Dukungan sistem informasi berbasis teknologi akan meningkatkan reliabilitas, validitas serta transparansi data dan informasi yang dibutuhkan dalam proses pengambilan keputusan pada setiap level.

Penyampaian proposisi nilai pada tiap segmen pelanggan tentu membutuhkan sumberdaya yang relevan. Sumberdaya utama dalam bisnis pelatihan adalah SDM yang berpengetahuan (sumberdaya intelektual), terlatih dan berorientasi pada kepuasan pelanggan. Oleh karenanya karyawan yang dimiliki perusahaan memperoleh fasilitas pengembangan diri yang dibutuhkan dengan metode pendampingan, pelatihan, maupun penugasan yang dimaksudkan untuk meningkatkan kapasitas personel. Selain itu dibutuhkan pula dukungan sistem dan teknologi informasi yang reliable, mudah digunakan dan terkini. Hal tersebut akan meningkatkan pengalaman positif bagi pengguna dan membantu efektivitas proses bisnis yang dijalankan perusahaan. Model bisnis pelatihan keahlian yang dijalankan perusahaan tidak menggunakan bahan dan peralatan yang berdampak negatif bagi lingkungan karena hanya menggunakan peralatan seperti laptop, gedung perkantoran serta beberapa peralatan penunjang praktikum yang tidak menghasilkan limbah maupun emisi.

Tidak setiap aktivitas harus dilakukan secara langsung oleh perusahaan, demikian pula halnya tidak semua sumberdaya harus disediakan sendiri oleh internal perusahaan. Karenanya berkembang model kemitraan dan pengalihdayaan. GHI Training bermitra dengan berbagai unit pada Universitas GHI (departemen, fakultas dan pusat studi) selaku komunitas lokal dalam penyediaan berbagai kepakaran yang dibutuhkan dalam menyusun beragam modul pelatihan. Pengembangan kemitraan dapat dilakukan dengan melakukan roadshow ke setiap unit di Universitas GHI dengan menawarkan model kolaborasi yang sesuai. Upaya lain yang perlu ditingkatkan manajemen dalam model kemitraan yang dibangun adalah aspek perlindungan terhadap kekayaan intelektual para narasumber. Selain menjalankan model kemitraan, perusahaan juga memiliki pemasok (supplier) dalam penyediaan kebutuhan penyediaan venue, katering dan kit. Umumnya ketiga hal tersebut diserahkan pengelolaannya pada perusahaan dalam grup yang sama yakni IPB Convention and Hotel, PT Serambi Botani Indonesia, PT Fits Mandiri serta IPB Press. Proses pengalihdayaan yang dijalankan perusahaan menggunakan energi listrik, gas, bahan pangan serta bahan kimia khususnya dalam penyediaan venue, katering dan kit. Meski demikian penggunaan bahan-bahan tersebut tidak signifikan dampaknya bagi lingkungan.

Aktivitas bisnis yang dijalankan perusahaan tentu berimplikasi pada munculnya struktur biaya. Biaya variabel (harga pokok produksi) pada bisnis pelatihan terdiri dari honorarium narasumber dan fasilitator, biaya sewa venue, katering, kit pelatihan, serta pemasaran. Sementara biaya tetap terdiri dari biaya pegawai (gaji, tunjangan dan asuransi), sewa kantor, perawatan dan pengembangan sistem informasi, penyusutan 
peralatan dan bahan praktikum serta penyusutan peralatan pendukung pelatihan (peralatan dokumentasi dan laptop). Biaya investasi portal video on demand ditambahkan sebagai bagian dari rencana perusahaan untuk mengembangkan model pembelajaran video on demand. Secara umum model bisnis yang dijalankan perusahaan tidak menimbulkan dampak negatif yang signifikan bagi lingkungan. Sementara dari sudut pandang sosial, kehadiran model-model pelatihan yang diselenggarakan perusahaan berpotensi menumbuhkan mindset instan dalam proses belajar. Hal ini dikarenakan pelatihan bersifat short course yang lebih mudah dan murah dibandingkan perkuliahan vokasional. Di sisi lain, pengelolaan perusahaan yang mengutamakan optimalisasi teknologi dan digitalisasi proses bisnis dapat menurunkan kebutuhan tenaga kerja.

Melalui analisis menggunakan TLBMC diperoleh gambaran bahwa bisnis yang dijalankan perusahaan dipandang dapat bertumbuh secara berkelanjutan. Secara ekologis, model bisnis yang dijalankan mampu memberikan manfaat bagi lingkungan dalam jangka panjang sekaligus relatif minim dampak negatifnya. Proses produksi, pemasaran, operasi, hingga distribusi produk/layanan tidak signifikan menghasilkan emisi dan limbah atau menurunkan kualitas air, tanah maupun udara. Sementara itu perusahaanjuga terus berkomitmen mengembangkan proses bisnis dengan dukungan teknologi yang dapat meminimalisir penggunaan kertas, tinta dan limbah perkantoran pada umumnya. Hal serupa juga terlihat dari sudut pandang sosial, dimana perusahaan mampu mengelola stakeholder dengan efektif. Perusahaan berupaya mengembangkan model bisnis yang sejalan dengan aspek sosial dan budaya masyarakat terkait pembelajaran dan perbaikan berkelanjutan. Budaya pelanggan yang menginginkan produk yang lebih baik, cara yang lebih mudah, proses yang lebih cepat, serta biaya yang lebih murah selaras dengan berbagai solusi yang berupaya ditawarkan oleh perusahaan. Sementara itu dari aspek ekonomi, model bisnis yang dikembangkan juga memiliki potensi besar untuk dikembangkan melalui pengembangan produk dan layanan dengan memperhatikan berbagai tren yang dapat berkembang di masa mendatang.

\section{Implikasi manajerial}

Penelitian ini menemukan insight bahwa dalam rangka menjaga keberlanjutan bisnis di masa depan manajemen perlu menaruh perhatian terhadap kualitas produk dan layanan serta pengembangannya yang sejalan dengan kebutuhan dan preferensi pengguna. Dalam rangka memastikan penyampaian konten serta substansi produk dan layanan tersebut, manajemen perlu melakukan optimasi proses pemasaran berbasis konten dengan memanfaatkan berbagai channel. Sementara itu, mengingat trainer merupakan kunci dari bisnis pelatihan keahlian, maka perlu dilakukan upaya mitigasi ketergantungan model bisnis terhadap trainer. Terakhir, manajemen perlu memastikan perbaikan berkelanjutan terhadap kapasitas dan kualitas SDM, sistem dan teknologi perusahaan. Faktor-faktor tersebut merupakan pondasi dari penguatan daya saing perusahaan di masa mendatang.

\section{KESIMPULAN DAN SARAN}

\section{Kesimpulan}

Secara umum hasil evaluasi terhadap faktor strategis internal dan eksternal menggambarkan bahwa perusahaan dalam posisi internal yang cukup kuat serta dapat merespon dengan baik peluang yang ada dan mengantisipasi ancaman yang muncul. Meski demikian upaya perbaikan berkelanjutan (continuous improvement) perlu terus dilakukan guna menjaga dan meningkatkan daya saing organisasi.

Analisis matriks IE memberikan gambaran bahwa perusahaan berada dalam kondisi menjaga dan mempertahankan (hold and maintain). Karenanya perusahaan disarankan fokus mengembangkan strategi penetrasi pasar dan pengembangan produk. Sejalan dengan penelitian Joyce dan Paquin (2016), melalui TLBMC dapat dilihat hubungan vertikal antar lapisan pada model bisnis GHI Training baik dari sudut pandang ekonomi, ekologi maupun sosial. Melalui analisis juga dapat terlihat bahwa secara esensial dari sudut pandang teoritis maupun praktik penggunaan TLBMC dapat membantu manajemen melihat dengan komprehensif model bisnis yang dikembangkan dan kaitannya dengan isu lingkungan maupun sosial yang berpengaruh terhadap keberlanjutan bisnis. Hal ini sejalan dengan hasil penelitian yang dilakukan oleh Furqon et al. (2019) dan Mu'min et al. (2018).

\section{Saran}

Dalam rangka mengimplementasikan hasil kajian, manajemen perlu melakukan pemantauan terhadap proses perubahan yang dicanangkan. Hal ini bertujuan 
agar target yang telah disusun dapat dicapai sesuai dengan harapan dalam periode waktu yang telah ditetapkan. Sebagai upaya pengembangan penelitian, perlu dilanjutkan penelitian yang menguji tingkat efektivitas implementasi strategi yang telah disusun.

\section{DAFTAR PUSTAKA}

Agustini SR. 2017. Perencanaan strategis sistem informasi bisnis pada lembaga kursus dan pelatihan Viakom Jambi. Jurnal Ilmiah Media Sisfo 11(1):736-751.

Amador MLB, Nicolas AL, Vila LE. 2008. Education and competence mismatches: job satisfaction consequences for workers. Journal Economic Literature 16(1):1-12.

Bao W. 2020. COVID-19 and online teaching in higher education: A case study of Peking University. Human Behavior and Emerging Technologies 2(2):113-115.

Basilaia G, Kvavadze D. 2020. Transition to online education in schools during a SARS-CoV-2 Coronavirus (COVID-19) pandemic in Georgia. Pedagogical Research 5(4):1-9.

David FR. 2011. Strategic Management: Concept and Case. Ed ke-13. New Jersey: Pearson

Diem A. 2014. Overeducation among graduates from universities of applied sciences: determinants and consequences. International Journal of Economics 2(1):27-43.

Furqon C, Sultan MA, Wijaya F. 2019. Business development of coffee farmers group using triple layered business model canvas. Journal of Business and Economics Review 4(4):163-170.

García-Muiña FE, Medina-Salgado MS, Ferrari AM, Cucchi M. 2020. Sustainability transition in industry 4.0 and smart manufacturing with the triple-layered business model canvas. Sustainability 12(2364).

Jourdan M, Baga LM, Harianto H. 2018. Arsitektur strategi pengembangan bisnis pelabuhan darat. Jurnal Manajemen Transportasi \& Logistik 5(3):204-214.

Joyce A, Paquin RL. 2016. The triple layered business model canvas: a tool to design more sustainable business models. Journal of Cleaner Production 135:1-13.

[LD UI] Lembaga Demografi Universitas Indonesia. 2018.Mismatchpendidikandanpekerjaan.https:// ldfebui.org/wp-content/uploads/2018/05/2018-
05-Mismatch.jpeg. [29 Okt 2020].

Mu'min MS, Anggara YP, Maulana RB. 2018. Identified of tobacco industry development in east java: error correction model approach and the tripled layer business canvas model application. Journal of Developing Economics 3(2):127-145.

Pemerintah Republik Indonesia. 2020. Peraturan Pemerintah Republik Indonesia Nomor 21 Tahun 2020 tentang Pembatasan Sosial Berskala Besar Dalam Rangka Percepatan Penanganan Corona Virus Disease 2019 (COVID-19). https:// covid19.go.id/p/regulasi/pp-no-21-tahun-2020tentang-psbb-dalam-rangka-penanganan-covid19. [29 Okt 2020].

Prasetyo BB, Baga LM, Yuliati LN. 2018. Strategi pengembangan bisnis Rhythm of Empowerment dengan pendekatan model bisnis kanvas. Jurnal Aplikasi Manajemen dan Bisnis 4(2):296-307.

Puncreobutr V. 2016. Education 4.0: New Challenge of Learning. St. Theresa Journal of Humanities and Social Sciences 2(2):92-97.

Qodri RA, Payangan OR, Baumassepe AN. 2019. Strengthening the business model of PT. Parlevliet Paraba Seafood using triple layered business model canvas. Hasanuddin Journal of Business Strategy 1(3):96-103.

Sari H. 2019. Strategi pengembangan model bisnis dengan menggunakan pendekatan triple layer business model canvas (study deskriptif pada perusahaan miski aghnia di Cibaduyut) [tesis]. Bandung: Universitas Pendidikan Indonesia.

Stubbs W, Cocklin C. 2008. Conceptualizing a "sustainability business model". Journal of Organization and Environment 21(2):103-127.

Sun L, Tang Y, Zuo W. 2020. Coronavirus pushes education online. Nature Materials. 19:687.

Umar H. 2010. Desain penelitian manajemen strategik: Cara mudah meneliti masalah-masalah manajemen strategik untuk skripsi, thesis dan praktek bisnis. Jakarta: Rajawali Press.

Wongwa RS. 2016. Perencanaan bisnis jasa pelatihan pendidikan entrepreneur "smart entrepreneur". Jurnal bisnis dan manajemen 52(11):142-158.

WulandariRA,FahmiI,NurmalinaR.2017.Perencanaan strategis dengan pendekatan balance scorecard pada perusahaan properti (studi kasus: Elang Group). Jurnal Aplikasi Bisnis dan Manajemen 3(2): 299-312. 